\section{Dung beetles and their role in the nature}

Adam Byk, Jacek Piętka

Summary:

Scarabaeoid beetles (Scarabaeoidea) inhabit all zoogeographical regions of the world. However, coprophagy as the type of nutritional specialization dominates among the scarabaeoid beetles. The number of dung beetles (coprophagous Scarabaeoidea) is estimated at about 7,000 species. There are about 460 of dung beetles species in Europe, and about 90 of dung beetles species in Poland. Dung beetles can be endocoprids (dwellers), paracoprids (tunnelers) or telecoprids (rollers). Endocopric species lay eggs directly into the dung, paracropic species dig earth tunnels of various lengths ending with brooding chambers beneath the dung, and telecopric species separate a portion of dung and roll it into round balls which are then transported, sometimes far from the original source of the dung, to a place where the beetles dig tunnels ending with brooding chambers. Such a variety of methods of using faeces by dung beetles cause an accelerated circulation of nutrients, increased soil aeration, plant spreading, and a reduction in the number of parasites (flies and nematodes). Among dung beetles presently encountered in Poland there are endocopric and paracopric species.

Key words: Scarabaeoidea, Scarabaeidae, Geotrupidae, dung beetles, scarab dung beetles, earth-boring dung beetles, animal faeces

received: 23.06 .2017 ; accepted: 23.07.2017; published: 13.12.2017
Whatever it is that dung beetle buries and abandons the next day, is by no means lost. Nothing is lost in the balance of life, the whole of the inventory remains constant. A small pellet of manure buried by an insect will make the neighboring patch of grass turn delightfully green. The ram will come over and pluck the whole patch, and thus the better the roast a man expects of him will be. Thanks to the dung beetle industry, we get a perfect bite of meat.

Jean Henri Fabre

\section{Introduction}

Insects are the most numerous group of animal species on Earth with their quantity estimated at around 1.5 million species. The largest group of the insects (over 400,000 species) belong to the order of beetles (Coleoptera). Scarabaeoidea is one of the superfamilies of the beetles, which inhabit all zoogeographical parts of the world. Most of them inhabit the tropical zone, and their number tends to rapidly decrease northwards (Tesar, 1957).

The Scarabaeoidea superfamily is dominated by a group of species that feed on animal dung (coprophages). The recently found dung fossils indicate the existence of dung beetles (coprophagous Scarabaeoidea) in the age of the dinosaurs, even before the evolution of mammals (Chin and Gill, 1996). Currently, the number of dung beetles is estimated at 7,000 species (Hanski and Cambefort, 1991).

In Europe, the dung beetles include primarily the representatives of two families: earth-boring dung beetles - Geotrupidae (approximately 60 coprophagous species) and scarab dung beetles - Scarabaeidae (approximately 400 coprophagous species).

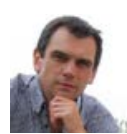

In Poland, the dung beetles fauna - formerly referred to by Hildt (1896) as "Domestic dung beetles" represents approximately 90 species. However, the prevalence of several of these species is yet to be confirmed by new finds.

The systematic arrangement and nomenclature of the species have been adapted from the "Catalogue of Palearctic Coleoptera” (Löbl and Löbl, 2016).

\section{Farther and deeper}

The dung beetles (coprophagous Scarabaeoidea) are the Endocoprid (dwellers), Paracoprid (tunnelers) or Telecoprid (rollers) insects (Bornemissza, 1976). The Endocoprid species lay their eggs directly in dung or in

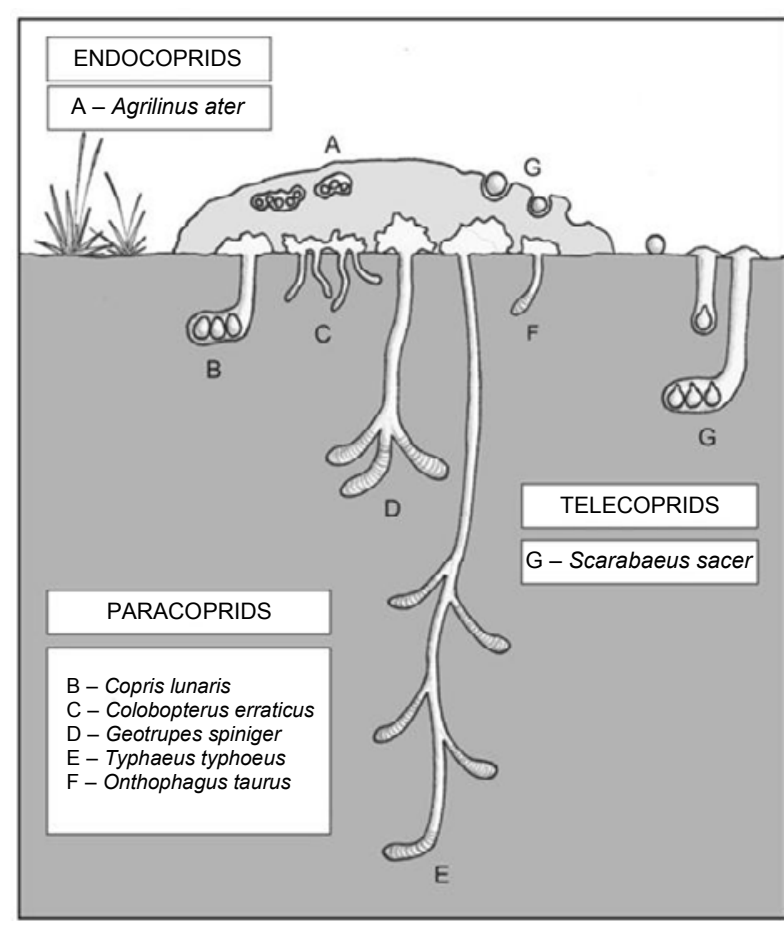

Fig. 1. Diagrams of dung beetles nests (drawn by J. Piętka). 
the top layer of the soil, directly underneath the dung. The Paracoprids dig tunnels of various lengths in the ground, underneath the faeces. The tunnels are terminated with hatching chambers. As regards the Telecoprids, upon earlier separation and formation of a piece of dung, they roll it away and dig their tunnels, terminated with hatching chambers, at considerable distances from the dung. The chambers are used for storing the transported portions of the dung (Fig. 1).

The dung beetles commonly found in Poland include the Endocoprid and Paracoprid species (Byk, 2011; Byk, 2012; Kamiński, Byk and Tykarski, 2015).

The Endocoprid grouping is represented by aphodiine dung beetles (Fig. 2). They are the dominant coprophagous beetles in northern Europe and play a significant role in disposing of dung, and thus in circulating the natural organic substances and providing nutrients to the flora (Fry and Lonsdale, 1991).

Agrilinus ater (DE GeER, 1774) (Fig. 2A) feed on fresh dung inside which females lay eggs. The eggs are laid as early as on the second day after the exposure of the dung, but most frequently within a period of 4 to 10 days after the exposure. The larvae prey in the vicinity of where the eggs are hatched (Hirschberger, 1998).

In the $19^{\text {th }}$ and $20^{\text {th }}$ centuries, a very beautifully colored dung beetle, Acrossus bimaculatus, (LAXmann, 1770) (Fig. 2B), was observed in the area of Warsaw. Here is what Hildt (1896) wrote about this particular species: "One can tell that it is the prettiest specimen of the Aphodidae group. Glittering, as if it was covered in porcelain topping [...]. An insect rarely seen in our region and nowhere to be found in some other years. [...] I found one specimen in Saska Kepa in 1863. [...] Another time, I found it in 1865 [...] and on April 19, 1868, I found as many as forty of them in cow dung [...]. The last one, I found in 1888 [...] and haven't found a single one ever since". In Poland, this particular species has not been

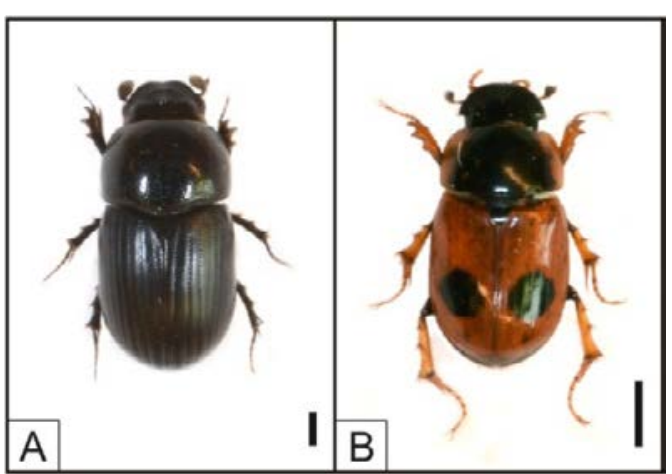

Fig. 2. Endocoprid aphodiine dung beetles: A - Agrilinus ater, B - Acrossus bimaculatus (photo by J. Piętka).

stumbled upon for nearly 100 years. In 1995, a site of the species was discovered near the village of Rudeńsk located close to Minsk in Belarus. Imagines and larvae were found directly in horse dung (Frolov and Akhmetova, 2006).

The aphodiine dung beetles grouping observable in Poland also includes species applying a slightly different method of using dung (Fig. 3).

Orodaliscus rotundangulus (REITTER, 1900) (Fig. $3 \mathrm{~A}$ ) lives in the burrows of speckled ground squirrel Spermophilus suslicus (GüLDENSTAEDT, 1770), bobak marmot - Marmota bobak (MüLlER, 1776) (Byk and Bidas, 2011), which is not present in our country, and little ground squirrel - Spermatophilus pygmaeus (PALLAS, 1778) (Martynov, 2007). In Poland, this beetle is observed on extremely rare occasions, in the form of a single specimen, and is known to exist only on 5 sites located in the Lublin Upland. Strong populations of this species are found in the "Popówka" and "Suśle Wzgórza" reserves. The swarming of this species takes place during the last days of April or in the first half of May. The beetles leave the squirrels' burrows during the afternoon or evening hours. From a nest chamber located at a depth of 60-150 $\mathrm{cm}$ and a tunnel (latrine) extending from it, the beetles leave the site via a short and slanted corridor (elbow) and then, they climb up the side-walls of the vertical corridors (wells). It is both, males and females that leave the burrows, and after that, they bury themselves underneath a moist soil, at a close distance to the exit holes (Byk and Bidas, 2011). The presence of this beetle species in traps filled with cattle dung bait indicates their coprophagous genus (Piasecki, 2013).

Contrary to the Endocoprids, the Colobopterus erraticus (LinnaEUs, 1758) (Fig. 3B), which is quite popular in our country, has a different way of behaving. A female of this species digs 4-10 curved tunnels in the soil, directly underneath the dung, at a depth of 3-5 cm $(10-11 \mathrm{~cm}$ on rare occasions). She always lays eggs oneby-one in a small-size cavity in the soil, most frequently in the lower part of the tunnel. It takes the beetle a few hours to fill the tunnel (or rather its lower part referred to as larder) and to create a sausage-like breeding lump (brood mass). The mass weighs between 0.6 and 4 grams. It is about $7 \mathrm{~mm}$ in diameter and from 1.5 to $3.5 \mathrm{~cm}$ in length. It takes approximately 10 days for the female to build a nest with 8 tunnels filled with nourishment for the offspring. The larvae feed on the dung collected by the female and, should their supplies run out, they move close to the dung located right above them. The metamorphose takes place in the soil, at a depth of 12-13 centimeters (Rojewski, 1983).

The aforementioned is similar to how the largest and sporadically observed in our fauna Coprimorphus scrutator (Herbst, 1789) (Ryc. 3C) behaves. Over the recent years, this species has been observed in Skowronno near Pińczów (Bidas, 2004), Tylawa near Dukla, Huta Polańska near Krempna, Wojkowa near Krynica Zdrój (Bidas and Cieślak, 2006), Żubracze near Cisna, and in Przełęcz Wyżna near Wetlina (Zięba and Dworakowski, 2008). It inhabits cow dung on the mountain pastures. 
These beetles copulate on dung and then each female digs directly underneath the dung 7-8 shallow and vertical tunnels. At the bottom of these tunnels, food is collected for the upcoming offspring and this is also where eggs are laid - always in the lower part of the breeding lump and in compliance with the "one tunnel-one egg" principle. At the initial stage, the larvae feed on food collected in the tunnels and switch to using the dung located above them at a later stage. Prior to the metamorphose stage, the larvae penetrate into the soil and build pupation chamber (Barbero and Palestrini, 1995). The last two dung beetles belong to the Paracoprid group of the species.

Typical Paracoprids (Fig. 4) are domestic species of the following genus: Anoplotrupes JeKEL, Geotrupes LATREILLE and Trypocopris MOTSCHULSKY.

Dor beetle - Anoplotrupes stercorosus (Scriba, 1791) (Fig, 4A), is the most common and widespread member of the earth-boring dung beetles (Geotrupidae) that inhabits the forests of Poland. It digs 15-35 cm thick tunnels in the soil which are terminated with breeding lumps. Borowski (1960) made a comprehensive investigation into the nourishment spectrum of the dor beetle and presented it to the public. His analysis of the breeding lumps showed that they consist of fragments of leaves, including needles, pieces of bark, and rotting moss. They include no fragments of mushroom fruitbodies or rotten wood. The total amount of the mold buried by beetles of this species is about 1,400 kg per hectare. The most attractive food for the imago dor beetle is dung of large animals as well as decomposed mushroom fruitbodies. Plewińska (2007) points out to the high level of attractiveness of rodent dung for the dor beetle, which is even higher than that of cow and horse dung. She also draws attention to a significant contribution of this dung to the beetle's diet. Therefore, one may come to a conclusion that the dor beetle fancies

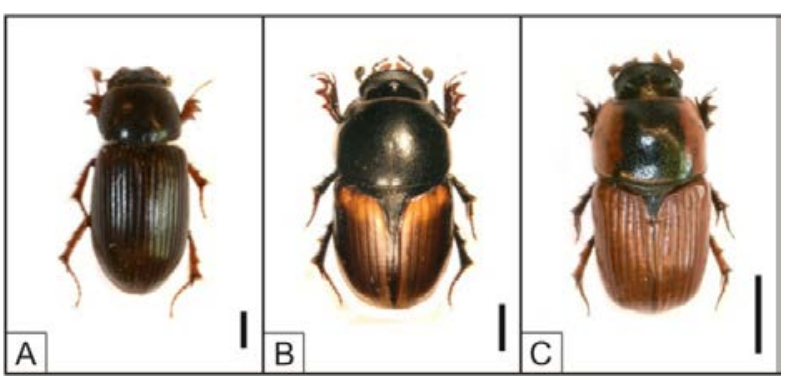

Fig. 3. Aphodiine dung beetles: A - Orodaliscus rotundangulus (photo by J. Piętka), B - Colobopterus erraticus (photo by T. Gazurek), C - Coprimorphus scrutator (photo by J. Piętka).

forests rich in rotten plants, animal faeces, and fungi. According to Teichert (1959), 7 pairs of the Geotrupes spiniger species (Marsham, 1802) (Fig. 4B) can bury over $12.6 \mathrm{~kg}$ of fresh manure during nesting. The mass of the dung buried by a single specimen exceeds by 560 times the mass of the beetle itself (Rojewski, 1980).

Another representative of the minotaur beetle - Typhaeus typhoeus (Linnaeus, 1758) (Fig. 4C) digs in the ground tunnels that are up to $100-150 \mathrm{~cm}$ deep (Brussaard, 1983). The nest of this species was once described by Fabre (1948), "This time, it is no longer the chamber of the scarab, homed dung beetle, or other, which is easy to dug out with the help of a pocket hoe, but a shaft the bottom of which can only be reached by digging for a few hours with a solid shovel. For this work, with the sun still beating down, the hands and legs become numb. Oh, my poor, old bones! Sensing such an interesting riddle under the ground and yet not being able to dig!" The minotaur beetle inhabits moorlands and pine forests on sandy soils where they feed on the excrements of rabbits, deer, roe, and sheep, more seldom of cows and horses (Burakowski, Mroczkowski and Stefańska, 1983). The beetles of this species are sometimes found under the carrion of large mammals (Byk, 2011). Nests are usually built directly under the dung or in their direct vicinity. Males and females work together while digging nests and transporting faeces. The females dig a tunnel and the males remove the excavated load of earth. The males put the faeces into the burrows where they initially grind it. In a sausage-like shaped hatching chamber, the females transform the faeces into a breeding lump about the size of a finger. An egg is laid in the soil under the breeding lump (Fabre, 1948). In laboratory conditions, the males first picked up the faeces located within a radius of 45 $\mathrm{cm}$ of the burrow entrance and then the faeces located at a greater distance. In the latter case, however, they often decided to dig a new entrance to the nest, and when the distance exceeded one meter, they usually left the nest and built new ones located closer to the faeces (Brussaard, 1983; Brussard and Visser, 1987).

Copris lunaris (Linnaeus, 1758) (Fig. 4D), which belongs to the scarab dung beetles, is a widespread species in our country. It likes to inhabit cattle and horse dung on sunlit pastures, sandy and loamy soils (Stebnicka, 1976a). The females dig in the ground, directly under the dung, a few centimeter-long tunnels that end with hatching chambers, where - together with the males they store food for their offspring (Myrcha, 1973). According to Rommel (1967), the males of this species transport the dung to the entrance of the tunnel, and the females take it into the hatching chamber. At the next stage, the females use the dung (previously collected in the chamber) to sculpt it into 4-8 pear-shaped breeding lumps and lay single eggs in their upper section. The females, and sometimes also the males, remain in the hatching chambers to take care of their offspring. They protect the breeding lumps filled with larvae and pupae and leave the nests with adult offspring (Myrcha, 1973; Mašán and Halliday, 2009).

In Poland, a large group of the Paracoprid species is represented by Onthophagus genus. Quite a number of 
these species are known for their sexual dimorphism. Males tend to have horn-like projections or even antlers. According to Fabre (1948), "No bull specimen typical for Swiss pastures has horns so exquisite and so beautifully curved" as the bull-headed dung beetle - Onthophagus taurus (Schreber, 1759) (Fig, 4A). It inhabits open sandy and limestone lands of xerothermic nature and the sunlit edges of forests (Burakowski, Mroczkowski and Stefańska, 1983). In our country, it is widespread in the pastures of the Bug River area. This beetle usually digs in the ground vertical sidewalks at the bottom of which a hatching chamber is built. Then, the side walls of the tunnel and the chamber are reinforced with the dung brought in from the outside. The egg is laid on one of the hatching chamber side walls, and then the chamber

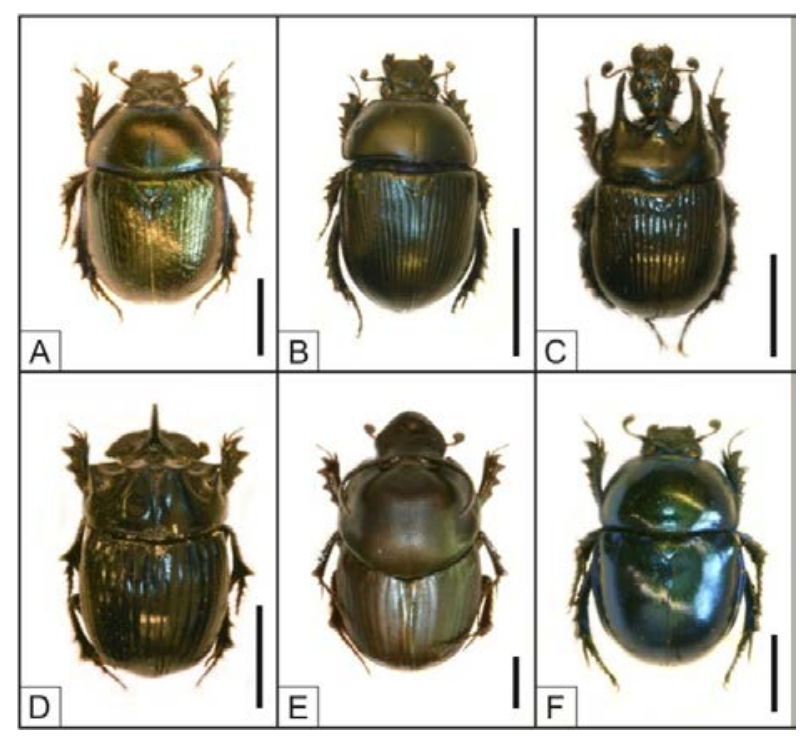

Fig. 4. Paracoprid dung beetles: A - Anoplotrupes stercorosus (dor beetle), B - Geotrupes spiniger, C Typhaeus typhoeus (minotaur beetle), D - Copris lunaris,

$\mathrm{E}$ - Onthophagus taurus (bull-headed dung beetle), F -

Trypocopris vernalis (spring dor beetle) (photo by J. Piętka) is filled with dung (Fabre, 1948; Halffter and Edmonds, 1982).

Sometimes, the minotaur beetle (Typhaeus typhoe$u s$ ), and sporadically the spring dor beetle - Trypocopris vernalis (Linnaeus, 1758) (Fig. 4F), are able to roll the dung at short distances. However, the Telecoprids group (Fig. 5) has no representatives in our domestic fauna.

A typical telecoprid species, Gymnopleurus geoffroyi (Fuessly, 1775) (Fig. 5A), was first observed more than a century ago in the vicinity of Ustron in the Cieszyn Silesia (Stebnicka, 1976a). According to Hildt (1896) this particular species, "[...] inhabits every type of dung. They form balls about the size of a bean and then lay eggs in them. If they find the ground unsuitable, they roll the ball to a more appropriate location, where they bury it and themselves deep in the ground. Although, these beetles live in groups, each pair manufactures its own ball. [...] They are totally absent in the Warsaw area. They appear only in the Radom Governorate and, more often, in the Hrubieszów district."

Sisyphus schaefferi (Linnaeus, 1758) (Fig. 5B), the second species of the Telecoprid group, was found over a century ago in Puławy and Janowiec of the Lublin Upland. It inhabits steppe areas, dry pastures, and mild

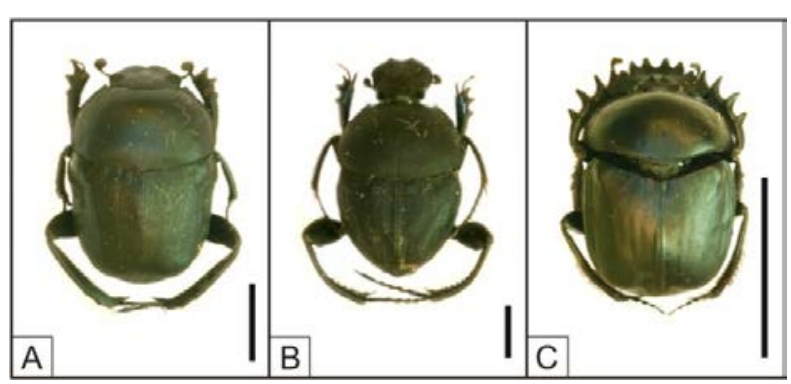

Fig. 5. Telecoprid true scarab dung beetles: A -

Gymnopleurus geoffroyi, B - Sisyphus schaefferi, C -

Scarabaeus sacer (sacred scarab beetle) (photo by J. Piętka) sunlit slopes. Adults feed on cattle dung, particularly that of the sheep. The food is collected in the form of pear-shaped balls stored in underground chambers which is where these beetles lay their eggs. However, they fail to care for their offspring (Burakowski, Mroczkowski and Stefańska, 1983). According to Hildt (1896), "It stays in fat manure and quite willingly in human excrements. It lives in pairs. Each pair forms little balls of the dung, buries them in the ground and lays eggs in them. They move in a clumsy, goat-like manner and with difficulty on even ground. [...] In our country, they are observed mostly in the southern part of the Lublin Governorate; they are pretty popular in the Galicia. [...] It is absent in the Warsaw area".

Sacred scarab beetle - Scarabaeus sacer (Linnaeus, 1758) (Fig. 5C), is the third species of the Telecoprid group reported in our country several years ago. J. A. Wolf's collection included a scarab specimen from the Cracow area. We know this from Karol Herman de Perthées' notes archived in the Institute of Systematics and Evolution of Animals of the Polish Academy of Sciences (PAN). However, the specimen itself was destroyed during a fire at the University of Kiev (Śliwa, 2003). At present day, the closest sites of the scarabs are located in Hungary (Scarabaeus typhon (Fischer von Waldheim, 1823) and S. pius (Illiger, 1803) and Ukraine (S. sacer and S. typhon). In the 18th, 19th and early 20th centuries, the scarabs were also found within the areas of the present-day Austria, the Czech Republic, and Slovakia. In 1961, the S. typhoon scarab was found in Kováčov on the Danube in the southern part of Slovakia. According to Hildt (1896), "Insects of this genus are not at all present in our region [...]. They are sometimes observed in the Podolia and Kherson Governorates [...] two specimens [...]. I found near the Rozdzielna railroad station". The city of Rozdzielna is currently located within the territory of Ukraine, approximately $60 \mathrm{~km}$ from 


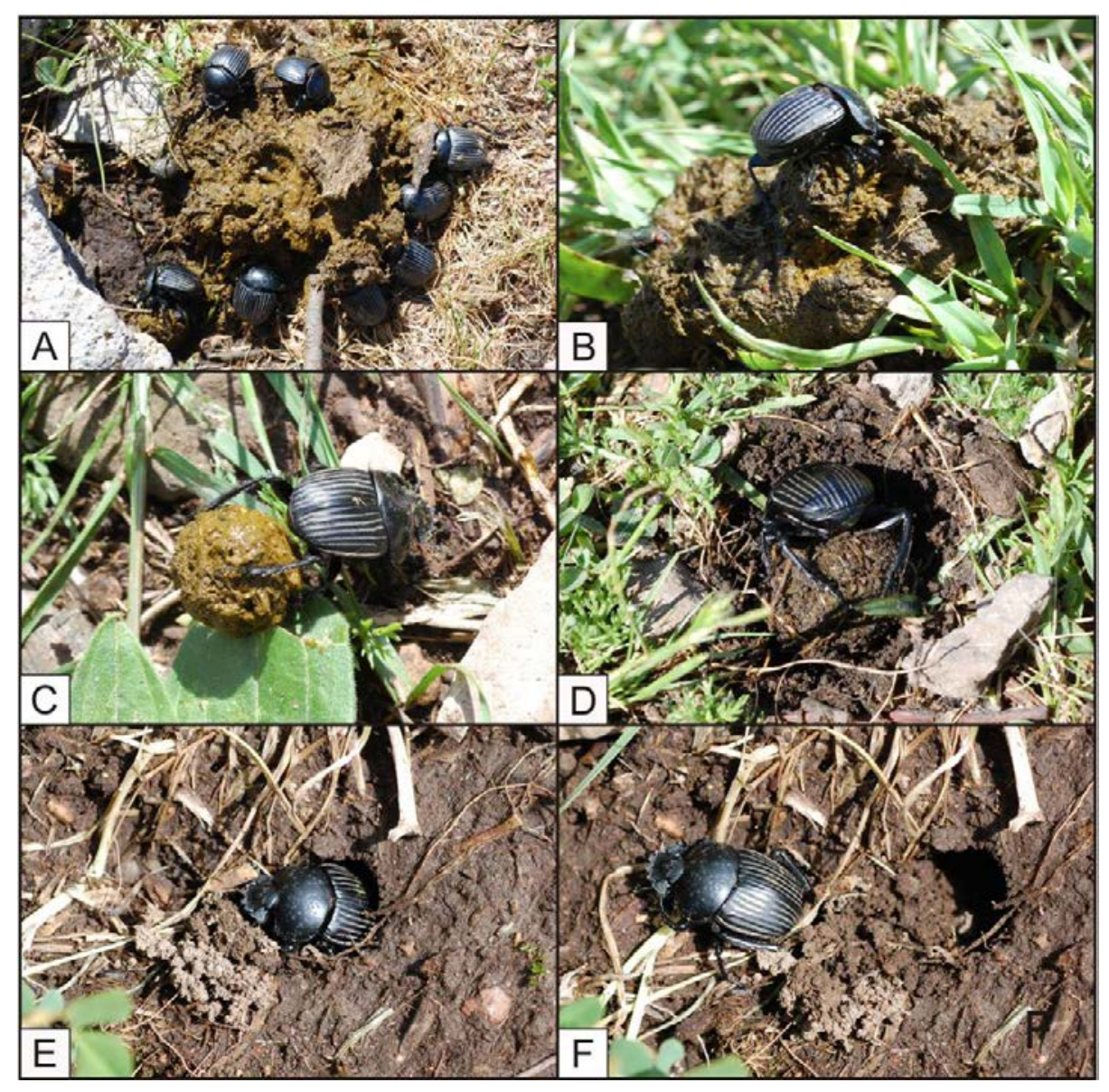

Fig. 6 A-F. Ateuchetus laticollis' dung handling method (photo by J. Piętka).

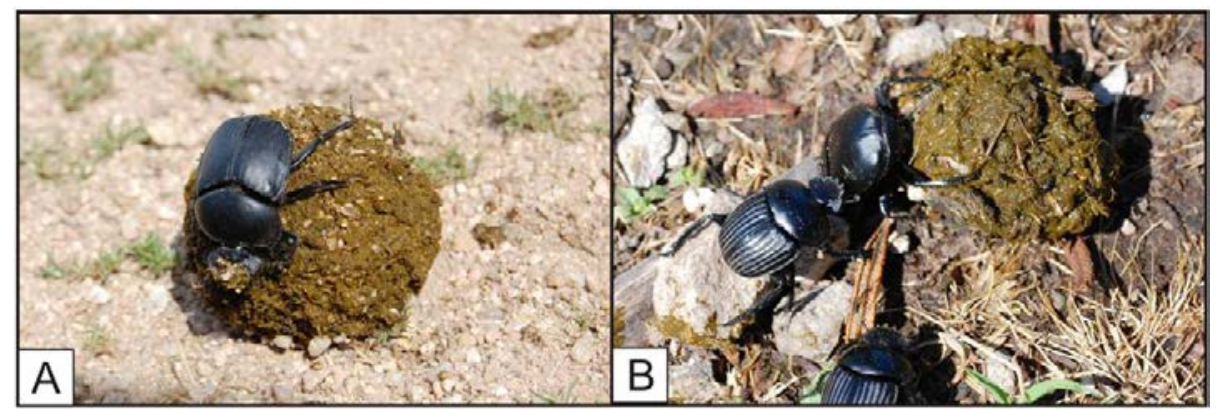

Odessa. The scarabs' natural habitat is fresh dung lying on the routes of the livestock (sheep, cows, and horses). The adult scarabs use their front section of the head and the legs (with distinctive tooth-like projections on the outer edges) to cut down portions of the dung.

On midsize pastures located near Cuglieri in Sardinia, the authors observed a swarm of Ateuchetus laticollis (Linnaeus, 1767) (Fig. 6) and the method the scarabs used to handle the dung. In the afternoon of a sunny May day, hundreds of specimens could be admired in the air and on the ground. One of the observed scarabs of this species cut the dung off and tentatively modeled a ball in 4 minutes. This beetle was vigorously moving his head and legs while turning around his own axis. After making suitably deep cuts, the pre-formed ball was separated from the rest of the dung under the weight of the beetle sitting on it. Next, the scarab embraced the ball with his hind legs and, standing still in vertical position with his head down, began to push his forelegs away from the ground, setting the ball in motion. Rolling a portion of fresh dung cut by the beetle caused its shape to become more spherical with its diameter reaching approximately $2 \mathrm{~cm}$. Larger scarabs (3-5 $\mathrm{cm}$ in diameter) are able to roll balls much larger in size $(3-5 \mathrm{~cm})$ and the largest specimens are skilled enough to manufacture a ball as large as $6 \mathrm{~cm}$. Quite frequently, the size of a ball exceeds that of the beetle itself (Byk and Piętka, 2011), and it is 10 to 20 times heavier (Doube and Dalton, 2003). The modeled ball of manure can be rolled by a scarab, or a pair of scarabs, even at a distance of several dozens of meters.

It is not uncommon that scarabs of the same species fight for the modeled ball. It happens that an individual who has put a lot of effort into modeling the ball is chased away by a stronger opponent. Sometimes, the specimens of two species, differing largely in size, compete for the ball. In Sardinia, the authors observed an 
unsuccessful attempt to take over a ball of a giant $S$. $t y$ phon scarab by 2 individuals of the smaller A. laticollis (Byk and Piętka, 2011) species (Fig. 7).

Fabre (1948) described this behavior in the following way, "I lack the more meaningful data to investigate the original causes of these dispossessions sanctified by tradition, of the abuse of power to gain a tiny bit of manure; I can only state that theft is a common practice amongst the scarabs. These dung-ball turners rob each other with unparalleled impudence." The scarabs dig 10-30 cm deep tunnels in the ground. The tunnels are terminated with a large-size chamber where the scarab places the ball which he has rolled to the site. It is this chamber where copulation takes place. Afterwards, the male leaves the nest and the female stays inside to form 1-3 breeding lumps from the ball. She lays eggs in the narrower sections of it and then leaves and covers the burrow afterward. In her life cycle, a single female can make dozens of nests. The hatching period takes from 5 to 12 days, the larva period from 30 to 35 days, and the pupa period - approximately 14 days. After the transformation period, depending on atmospheric conditions, the young beetles remain in the breading lumps until late autumn or spring. Once the indoor growing period has come to an end, the majority of the manure, which has been digested by the beetles, is left in the nest and is used to enrich the soil with organic substances (Byk and Piętka, 2011).

\section{The colder it gets, the lower the number of species}

As we advance towards the south of Europe, the number of individuals of coprophagic species belonging to the Scarabaeidae family increases amongst the representatives of the Scarabaeoidea superfamily, both in open and forested areas. They are dominated by species of the following genus: Onthophagus, Gymnopleurus, Sisyphus and Scarabaeus (Balthasar, 1964). Concurrently, the number of individuals of the Geotrupidae species tends to be reduced (Byk, 2012). According to Hortal et al. (2011), no low-temperature adaptation mechanisms were developed amongst the representatives of the Onitini and Scarabaeini tribes that would allow new areas to colonized or the species to survive in northern Europe. Located in northeastern Italy, the La Mandria Park a patchwork of the open and forested areas - as much as 94\% of the coprophagous Scarabaeoidea were the Scarabaeidae (including 32.5\% of the Aphodiinae specimens) and the Geotrupidae specimens constituted as little as $6 \%$ of the group (Barbero et al., 1999).

Across the pastures of Poland, the core of the coprophagous Scarabaeoidea groupings consist of the Scarabaeidae, but the Aphodiinae subfamily, i.e. the Acrossus rufipes (Linnaeus, 1758), Agrilinus ater, Aphodius pedellus (De Geer, 1774), Bodilopsis rufa (Moll, 1782), Chilothorax distinctus (Müller, 1776), Colobopterus erraticus, Esymus pusillus (Herbst, 1789), Eupleurus subterraneus (Linnaeus, 1758), Melinopterus prodromus (Brahm, 1790), M. sphacelatus (Panzer, 1798), and Othophorus haemorrhoidalis (Linnaeus, 1758) (Breymeyer, 1974; Stebnicka, 1976b; Bunalski, 1996a, b; Żuk, 2005; Górz, 2007). The core of the coprophagous Scarabae oidea groupings in the forests of Poland are made by two species of the Geotrupidae - the dor beetle ( $A n$ oplotrupes stercorosus) and the spring dor beetle (Try pocopris vernalis). The core is sometimes supplemented by the Acrossus depressus (Kugelann, 1792), A. rufipes, Aphodius pedellus, Chilothorax distinctus, Euorodalus coenosus (Panzer, 1798), and Planolinus fasciatus (Olivier, 1789) (Szyszko, 1983; Szwałko, 1995; Byk, 2011, 2012; Byk and Węgrzynowicz, 2015; Kamiński, Byk and Tykarski, 2015). The dor beetle plays a particularly important role in our domestic forests. It is a frequent inhabitant of the pine forests growing on the wooded areas and is observed in much larger numbers in the forests growing on the former farmlands. By inhabiting the forest stands growing on the former farmlands, by digging tunnels and burying wild animal dung and rotten leaves, it changes the properties of the post-agricultural soil hollowing and speeds up the forest-type land forming process (Byk, 2004; Byk and Semkiw, 2010). The above considerations show that open areas (meadows, pastures, fallows) as well as wooded areas are inhabited by groups of dung beetles of different structure (composition and quantity of the species).

\section{First come, first served}

A large quantity of dung beetles forces individual species to compete for food of an ephemeral nature. It appears suddenly and disappears within a short time or is unsuitable to inhabit. The result of this competition includes, without limitation, the previously presented different strategies the Endocoprids, Paracoprids, and Telecoprids apply to deal with dung. It is also extremely important to have the time necessary to reach the dung. The "first come, first served" strategy has been adopted by a large group of Telecoprids. Quite often, the Telecoprids find dung within a few minutes after its appearance as only the fresh dung is suitable for modeling a ball. To do this, the scarabs sometimes follow directly a herd of sheep. Their rush was described by Fabre (1948), "Who is that stepping so hastily, as if afraid of being late? Long legs are moving quickly and awkwardly as if set in motion by an invisible mechanism hidden in the insect's stomach; little red horns distributed in a fan-like manner - a sign of restless lust. Here it comes - it's already arrived running over a few fellow revelers. It is Scarabaeus sacer, the sacred scarab beetle". The Paracoprids and Endocoprids usually come to 
dung within the first several days following the dung's appearance. The Melinopterus Mulsant or Chilothorax Mотschulsky beetles of the Aphodiinae subfamily are usually there within the first few hours and the Aphodius Illiger and Teuchestes Mulsant - within the first few days. A similar way of conduct is attributable to the beetles of the Geotrupes and Onthophagus genera and the Ammooecius Mulsant genus is keen on inhabiting old dung, e.g. the one that appears in the spring once the snow has thawed. An unusual "sit and wait" strategy has been adopted by some of the tropical species of the Canthon HoffmannsegG genus. The amount of dung in neotropical forests is limited due to small quantities of large vertebrates, and for this reason finding the location of dung is an important element of the survival strategy. Beetles which first come to dung have an advantage over those arriving at a later time. The coprophagous tumblebugs (Canthon sp.) dwells in areas located close to the anus of arboreal monkeys the brown-haired Callicebus brunneus (Wagner, 1842) titi and Pithecia irrorata (Gray, 1842) saki monkeys. The imagines of this beetle inhabit ape dung already during defecation and fall from the trees down on the ground together with the dung (Jacobs et al., 2008). A similar way of conduct is attributable to species of the Uroxys Westwood and Pedaridium Harold genera. They inhabit the sloth's fur and leave it with their hosts' dung in which they continue to feed and lay their eggs (Halffter and Mathews, 1966; Ratcliffe, 1980; Howden and Young, 1981; Waage and Best, 1985). In Australia, 6 species of the Onthophagus genus dwell on marsupials. They cling on the marsupial's fur thanks to a specific structure of their claws (Matthews, 1972b). They also fall to the ground together with the marsupials' dung where they continue to develop.

\section{What's in it for us?}

The dung beetles (coprophagous Scarabaeoidea) play an extremely significant role in natural ecosystems, especially in the circulation of elements and secondary dispersal of seeds (Nichols et al. 2008). According to Rojewski (1980), Bunalski (1995) and Górz (1999), the role of the coprophages in meadow ecosystems consists in:

- Preventing the occurrence of the "dung pollution" phenomenon by reducing the mass of animal dung;

- Stimulating the dung mineralization process by burying and grinding it;

- Aerating and improving the structure of the soil by digging tunnels at various depths;

- Improving the amount humus in the soil by burying the dung;

- Reducing the number of coprobiontic dipterans (including the bloodsucking species);

- Reducing the quantity of parasitic nematodes by crushing their eggs.

According to Rembiałkowska (1980), the role of the pasture and forest species of the dung beetles is similar and consists in grinding and mixing of the soil with faeces of different species of mammals. A slightly different role is played by the dor beetle, which enriches the deeper, mineral layers of the soil with organic matter by burying the forest litter in the form of breeding lumps. This is of special importance for meager forest habitats where saprophagous macrofauna, e.g. earthworms, is rarely observed. The commonness and the role of the dung beetles are best evidenced by numbers:

- 10 specimens of the minotaur beetle (Typhaeus typhoeus) species can bury around 400 balls of rabbit dung in 25 days (Spaney, 1910);

- On a pasture located near Berlin, there were 825 specimens of the aphodiine dung beetles, 38 spe- cimens of the earth-boring dung beetles and 70 specimens of the Onthophagus genus dwelling in a portion of sheep dung, and 92 specimens of the Geotrupes stercorarius (Linnaeus, 1758) (Burmeister, 1936) species were found in a portion of horse dung;

- European species of the earth-boring dung beetles during the nest building period bury approximately from 0.2 to $0.7 \mathrm{~kg}$ of dung (Teichert, 1959);

- In Algeria, some 450 specimens of the Gymnopleurus genus and 190 other dung beetles in a single, $\varnothing 35 \mathrm{~cm}$ portion of cow dung, and 31 scarabs in another portion of dung (Balthasar, 1963) were observed;

- In Algeria, 80 beetles of the Thorectes Mulsant genus and Stereopyge A. Costa subgenus were observed on each square meter of a cornfield with freshly dispersed manure; each of these beetles buried 20 grams of dung; therefore, 800,000 specimens buried almost 16 tons of dung per hectare (Balthasar, 1963);

- In the Johannesburg area, there were usually 400 specimens of the Aphodiinae subfamily, 50 specimens of the Onthophagus genus, 50 specimens of the Oniticellus genus, 40 specimens of the Onitis genus, 2 specimens of the Copris genus, and 5 specimens of the Sisyphus genus (Gillard, 1967);

- Parasitic flies of the Haematobia irritans (Linnaeus, 1758) species cause approximately $\$ 730$ million in losses to cattle farming (Drummond et al., 1981), while the dung beetles can reduce the number of these flies by as much as $95 \%$ (Bornemissza, 1970, 1976);

- Under laboratory conditions, a pair of specimens of the Onitis genus can bury $0.7 \mathrm{~kg}$ of dung within 10 days' time (Doube and Dalton, 2003); 
- It is estimated that the dung beetles allow the US farmers to save $\$ 380$ million a year (Losey and Vaughan, 2006).

The key evidence of the tremendous importance of the dung beetles for nature is the role they played in Australia. In 1778, the Europeans settled in Australia and brought with them many species of crops and livestock. As cattle farming developed across the entire country, along came unprecedented pollution of pastures with dung (the so-called dung pollution) as well as the mass emergence of flies developing in the dung. Unfortunately, it also included the parasitic and bloodsucking species. Due to dung pollution, the area of pastures available to animals was rapidly decreasing. Under the country's climatic conditions, the dung quickly dried up and turned into "crust" that remained in place for several years. For this reason, the further development of sheep, cows, and horses has been questioned. The main reason for this was the lack of native coprophages that could grow in the cattle dung. Therefore, further development of sheep, cow and horse farming became pretty questionable. The main reason of this situation was the lack of domestic coprophages that could develop in animal dung. Domestic dung beetles have evolved together with the marsupials and failed to adopt the process of inhabiting cattle dung (Tyndale-Biscoe, 1971; Mathews, 1972b). Dung beetles in Africa, Asia, and Europe have evolved together with large ruminants and learned to use their faeces (Waterhouse, 1974; Bornemissza, 1976). It was, therefore, accepted that they could accelerate the dung decaying process on Australian pastures, so they were put to work. Between the years of 1970 and 1980, over 50 species of African and European dung beetles were sent from South Africa to Australia as part of the "Dung Beetle Project". 43 species of the dung beetles successfully passed the incubation and quarantine process and were then released to the pastures. As a result, a number of pastures polluted with dung drastically decreased. The key "heroes" included: gazella scarab Onthophagus gazella (Fabricius, 1787), northern sandy dung beetle - Euoniticellus intermedius (Reiche, 1850), alexis dung beetle - Onitis alexis (Klug, 1835), humpbacked dung beetle - Onthophagus binodis (Thunberg, 1818), and bull-headed dung beetle (Onthophagus taurus) (Edwards, 2007).

From among the insects that defend us against dangerous waste, shamelessly decaying in the rays of sunshine, dung beetles deserve most of the attention (Fabre, 1948).

\section{Acknowledgments}

We would like to thank Kornelia BYK for her help with digitizing the drawings and to Tomasz GAZUREK for his help with digitizing the photographs and for making available the Colobopterus erraticus photograph.

The authors of this article were inspired by the „Żuki czyli gnojowce krajowe" (Domestic dung beetles) work of Ludwik Fryderyk Hildt and by Jean-Henri Casimir Fabre's works devoted to the life of insects.

\section{References}

Balthasar V (1963). Monographie der Scarabaeidae und Aphodiidae der palaearktischen und orientalischen Region. Band 1. Scarabaeinae, Coprinae (Pinotini, Coprini). Verlag dre Tschechoslowakischen Akademie der Wissenschaften, Prag.

Balthasar V (1964). Monographie der Scarabaeidae und Aphodiidae der Palaearktischen und Orientalischen Region. Band 3. Aphodi idae. Verlag der Tschechoslowakischen Akademie der Wissenschaften, Prag.

Barbero E, Palestrini C (1995). Aphodius (Coprimorphus) scrutator descrizione della larva e note di biologia riproduttiva. Fragmenta entomologica, 26(2): 341-352

Barbero E, Palestrini C, Rolando A (1999). Dung beetle conservation effects of habitat and resource selection (Coleoptera: Scarabaeoidea). Journal of Insect Conservation, 3: 75-84.

Bidas M (2004). Interesujące gatunki żuków koprofagicznych (Coleoptera: Scarabaeoidea) na Wyżynie Małopolskiej. Wiadomości entomologiczne, 23(4): 245-246.

Bidas M. Cleślak R (2006). Nowe stanowiska Aphodius (Coprimorphus) scrutator (Herbst, 1789) (Coleoptera: Scarabaeoidea) w Polsce. Wiadomości entomologiczne, 25(3): 183

Borowski S (1960). Geotrupes stercorosus (Sc.) (Coleoptera, Scarabaeidae) w Białowieskim Parku Narodowym. Fragmenta faunistica, 8(23): 337-365.

Bornemissza GF (1970). Insectary studies on the control of dung breeding flies by the activity of the dung beetle, Onthophagus gazelle F. (Coleoptera: Scarabaeidae). Australian Journal of Entomology, 9(1): 31-41.

Bornemissza GF (1976). The Australian dung beetle project: 1965 1975. Australian Meat Research Committee Review, 30: 1-32.

Breymeyer A (1974). Analysis of a sheep pasture ecosystem in the Pieniny Mountains (The Carpatihians). Ekologia Polska, 22: 617634.

Brussaard L (1983). Reproductive behaviour and development of the dung beetle Typhaeus typhoeus (Coleoptera, Geotrupidae). Tijdschrift voor Entomologie, 126: 203-231.

Brussaard L, Visser WJF (1987). Dung exploitation by the dung beetle Typhaeus typhoeus (Col., Geotrupidae). Oecologia, 72: 21-27.

Bunalski M (1995). Analiza zgrupowań chrząszczy koprofagicznych (Coleoptera, Scarabaeoidea) na pastwiskach w okolicach Szamotuł. Praca doktorska - maszynopis, Biblioteka AR w Poznaniu.

Bunalski M (1996a). Żuki koprofagiczne (Coleoptera, Scarabaeoidea) okolic Szamotuł. Cz. I. Analiza faunistyczna. Wiadomości entomologiczne, 15(3): 139-146.

Bunalski M (1996b). Żuki koprofagiczne (Coleoptera, Scarabaeoidea) okolic Szamotuł. Cz. II. Wiadomości entomologiczne, 15(4): 217224.

Burakowski B, Mroczkowski M, Stefańska J (1983). Chrząszcze Coleoptera. Scarabaeoidea, Dascilloidea, Byrrhoidea i Parnoidea. Katalog Fauny Polski, 23(9): 1-294.

Burmeister F (1936). Bauten und Brutfürsorge der Mistkäfer. Entomologische Blätter, 32: 24-30, 58-65.

Byk A (2004). Zmiany liczebności żuka leśnego Anoplotrupes stercorosus (HARTM.) pod wpływem zalesień. Sylwan, 148(3): 28-34.

Byk A (2011). Abundance and composition of Geotrupidae (Coleoptera: Scarabaeoidea) in the developmental cycle of pine stands in Człuchów Forest (NW Poland). Baltic Journal of Coleopterology, 11(2): 171-186.

Byk A (2012). Abundance and composition of coprophagous Scarabaeidae (Coleoptera: Scarabaeoidea) in the developmental cycle of pine stands in Człuchów Forest (NW Poland). Baltic Journal of Coleopterology, 12(2): 127-144.

Byk A, Bidas M (2011). Nowe stwierdzenia Aphodius rotundangulus Reitter, 1900 (Coleoptera: Scarabaeidae: Aphodiinae) w Polsce $\mathrm{z}$ uwagami o jego bionomii. Wiadomości entomologiczne, 30(4): 264.

Byk A, Piętka J (2011). Z życia skarabeuszy. Ekonatura, 10: 10-11.

Byk A, Semkiw P (2010). Habitat preferences of the forest dung beetle 
Anoplotrupes stercorosus (Scriba, 1791) (Coleoptera: Geotrupidae) in the Białowieża Forest. Acta Scientiarum Polonorum Silvarum Colendarum Ratio et Industria Lignaria, 9(3-4): 17-28.

Byk A, Wegrzynowicz P (2015). The Structure and Seasonal Dynamics of Coprophagous Scarabaeoidea (Coleoptera) Communities in Later Developmental Stages of Pine Stands in NW Poland. Journal of the Entomological Research Society, 17(3): 39-57.

Chin K, Gill BD (1996). Dinosaurs, dung beetles, and conifers: participants in a Cretaceous food web. Palaios, 11: 280-285.

Drummond RO, Lambert G, Smalley HE, Terrill CE (1981). Estimated losses to livestock pests. Handbook of Pest Management in Agriculture, 1: 111-127.

Doube B, Dalton G (2003). Dung Beetles Transform a pollutant into an environmental and agricultural benefit. A practical guide to the Benefits, Behaviour, Species, Establishment, Management and Monitoring of dung beetles. Fleurieu Beef Group Inc. Australia. current status and future directions. A Landcare Australia project "Dung Beetles for Landcare Farming" funded by The Orica Community Foundation.

Fabre JH (1948). Z życia owadów. Spółdzielnia wydawnicza „Wiedza", Warszawa.

Frolov AV, Akhmetova LA (2006). Description of the Third-instar Larva of Aphodius bimaculatus (Laxmann) (Coleoptera, Scarabaeidae). Entomological Review, 86(4): 433-437.

Fry R, Lonsdale D (1991). Grassland Habitats. In: Fry R, Lonsdale D, Eds. Habitat Conservation for Insects - A Neglected Green Issue. The Amateur Entomologists' Society, Middlese, 93-115.

Gillard P (1967). Coprophagous beetles in pasture ecosystems. Journal of the Australian Institute of Agricultural Science, 33: 30-34.

Górz A (1999). Zgrupowania koprofagicznych chrząszczy (Coleoptera, Scarabaeidae) z terenu południowej części Wyżyny Krakowsko-Częstochowskiej. Praca doktorska - maszynopis, Biblioteka AP w Krakowie.

Górz A (2007). Changes in the coprofagous beetle fauna of the Scarabaeoidea (Coleoptera) superfamily on the Krakow-Czestochowa Upland. Polish Journal of Entomology, 76: 199-206.

Halffter G, Edmonds WD (1982). The nestingsbehavior of dung beetles (Scarabaeinae): an ecological and evolutive approach. Instituto de Ecologia, Mexico, D. F.

Halffter G, Mathews EG (1966). The natural history of dung beetles of the subfamily Scarabaeinae (Coleoptera, Scarabaeidae). Folia Entomológica Mexicana, 12-14: 1-312.

Hanski I, Cambefort Y (1991). Dung Beetle Ecology. Princeton University Press. Princeton, New Jersey.

Hildt LF (1896). Żuki czyli gnojowce krajowe. Pamiętnik Fizyografic$z n y, 14(3): 153-228$.

Hirschberger P (1998). Spatial distribution, resource utilisation and intraspecific competition in the dung beetle Aphodius ater. Oecologia, 116: 136-142.

Hortal J, Diniz-Filho JAF, Bini LM, Rodríguez MÁ, Baselga A, Nogués-Bravo D, Rangel TF, Hawkins BA, Lobo JM (2011). Ice age climate, evolutionary constraints and diversity patterns of European dung beetles. Ecology Letters, 14: 741-748.

Howden HF, Young OP (1981). Panamanian Scarabaeinae: Taxonomy, distribution, and habits (Coleoptera, Scarabaeidae). Contributions of the American Entomological Institute, 18: 1-204.

Jacobs J, Nole I, Palminteri S, Ratcliffe B (2008). First Come, First Serve: "Sit and Wait" Behavior in Dung Beetles at the Source of Primate Dung. Neotropical Entomology, 37(6): 641-645.

Kamiński MJ, Byk A, Tykarski P (2015). Seasonal and Diel Activity of Dung Bettracted (Coleoptera: Scarabaeoidea) Attracted to European Bison Dung in Białowieża Primeval Forest, Poland. The Coleopterists Bulletin, 69: 83-90.

Löbl I, Löbl D (eds) (2016). Catalogue of Palaearctic Coleoptera. Scarabaeoidea, Scirtoidea, Dascilloidea, Buprestoidea and Byrrhoidea. Volume 3. Revised and Updated Edition. Brill, Leiden-Boston.

Losey JE, Vaughan M (2006). The economic value of ecological services provided by insects. BioScience, 56: 311-323.

Martynov VV (2007). Description of larvae Aphodius (Pseudacrossus) thermicola Sturm, 1800, Aphodius (Orodaliscus) rotundangulus Reitter, 1900 and Aphodius (Planolinus) fasciatus Olivier, 1789 (Coleoptera: Scarabaeidae: Aphodiinae). Izvestiya Khar'kovskogo entomologicheskogo obshchestva, 14(1-2): 25-31.

Mašán P, Halliday B (2009). Mesostigmatid mites associated with the dung beetle Copris lunaris (Coleoptera: Scarabaeidae). European Journal of Entomology, 106: 545-550.

Matthews EG (1972a). A revision of the scarabaeine dung beetles of Australia. II. Tribe Scarabaeini. Australian Journal of Zoology Supplementary Series, 9: 3-330

Mathews EG (1972b). A revision of the scarabaeine dung beetles of Australia. I. Tribe Onthophagini. Australian Journal of Zoology Supplementary Series, 9: 1-330.

Myrcha A (1973). Bioenergetics of the development period of Copris lunaris (L.). Ekologia Polska, 21: 13-35.

Nichols E, Spector S, Louzada J, Larsen T, Amezquita S, Favila ME (2008). Ecological functions and ecosystem services provided by Scarabaeinae dung beetles. Biological Conservation, 141: 14611474.

Piasecki J (2013). Koprofagiczne poświętniki (Coleoptera: Scarabaeoidea) Rezerwatu „Popówka”. Praca inżynierska, Katedra Ochrony Lasu i Ekologii SGGW w Warszawie, Warszawa.

Plewińska B (2007). The effect of food odour on food prefeerence, activity and density of dung beetle Geotrupes stercorosus (Scriba, 1791) in e mixed coniferous forest. Polish Journal of Ecology, 55(3): 495-509.
Ratcliffe BC (1980). New species of Coprini (Coleoptera: Scarabaeidae: Scarabaeinae) taken from the pelage of three toed sloth (Bradypus tridactylus L.) (Edentata: Bradypodidae) in central Amazonia with a brief commentary on scarab-sloth relationships. The Coleopterists Bulletin, 34: 337-350.

Rembiałkowska E (1980). Rola chrząszczy koprofagicznych z rodziny Scarabaeidae w ekosystemach łąkowych i leśnych strefy umiarkowanej. Wiadomości ekologiczne, 26: 253-263.

Rojewski C (1980). Znaczenie żuków gnojowych w przyrodzie i gospodarce człowieka. Przeglad Zoologiczny, 24(4): 431-438.

Rojewski C (1983). Observations on the nesting behavior of Aphodius erraticus (L.) (Coleoptera, Scarabaeidae). Polskie Pismo Entomologiczne, 53: 271-279.

Rommel E (1967). Ernaehrungsbiologie und Brutpflegeverhalten des Kleinen Mondhornkaefers Copris lunaris (L.) (Col., Scarab.). Eine Vergleichsstudie zu den Arbeiten ueber den Spanischen Mondhornkaefer Copris hispanus (L.). Nachrichtenblatt der Bayerischen Entomologen, 16: 8-13, 20-28.

Spaney A (1910). Beiträge zur Biologie unserer einheimischen Rosskäfer. (Col.). Deutsche entomologische Zeitschrift, 1-6: 625 634.

Stebnicka Z (1976a). Żukowate - Scarabaeidae. Grupa podrodzin: Scarabaeidae laparosticti. Klucze do rozpoznawania owadów Pol$s k i, 19(28 \mathrm{a}): 1-139$

Stebnicka Z (1976b). Żukowate (Coleoptera, Scarabaeidae) Pienin. Fragmenta faunistica, 21: 331-351.

Szyszko J (1983). Scarabaeidae. In: Szujecki A, Ed. The process of Forest Soil Macrofauna Formation after Afforestation of Farmland. Warsaw Agricultural University Press, Warsaw, 112-116.

Szwałko P (1995). Chrzaszcze żukowate (Coleoptera: Scarabaeoidea) Puszczy Białowieskiej w aspekcie dotychczasowych badań monitoringowych na terenie północno-wschodniej Polski. Prace Insty tutu Badawczego Leśnictwa - Seria A, 794: 108-128.

Śliwa J (2003). Skarabeusze egipskie. Zakład Narodowy im. Ossolińskich - Wydawnictwo, Wrocław.

Teichert M (1959). Die bodenbiologische Bedeutung der coprophagen Lamellicornier. Wissenschaftliche Zeitschrift der Martin Luther-Universität Halle-Wittenberg, Math.-Nat., 8(6): 879-882.

Tesař Z (1957). Brouci listorozí. Fauna ČSR. Československá Akademie Věd, Praha.

Tyndale-Biscoe H (1971). Life of Marsupials. Edward Arnold, Australia.

Waage JK, Best RC (1985). Arthropod associates of sloths. In: Montgomery GG, Ed. The evolution and ecology of armadillos, sloths, and vermilinguas. Smithsonian Institution Press, Washington, D.C., 319-322.

Waterhouse DF (1974). The biological control of dung. Scientific American, 230: 100-109. 
Zięba P, Dworakowski M (2008). Aphodius (Coprimorphus) scrutator (Herbst, 1789) (Coleoptera: Scarabaeoidea) w Bieszczadach. Wiadomości entomologiczne, 27(3): 168.

Żuk K (2005). Koprofagiczne żukowate (Coleoptere: Scarabaeoidea)

pastwiska w Jarach na Wzgórzach Trzebnickich. Wiadomości entomologiczne, 24(3): 153-164. 